\title{
PELATIHAN PEMBUATAN STIK KANGKUNG UNTUK GURU DAN SISWA SMA WIJAYA PUTRA SURABAYA
}

\author{
Sukarjati $^{*}$, Ngadiani $^{2}$, Diah Karunia Binawati ${ }^{3}$, Purity Sabila Ajiningrum ${ }^{4}$, Vivin \\ Andriani $^{5}$ \\ ${ }^{1}$ Program Studi Biologi, FST, Universitas PGRI Adi Buana Surabaya, Surabaya, Indonesia \\ *Email: sukarjati@unipasby.ac.id
}

\begin{tabular}{|c|c|}
\hline Informasi Artikel & Abstrak \\
\hline $\begin{array}{l}\text { Diterima: 15-06-2021 } \\
\text { Disetujui: 30-06-2021 } \\
\text { Dipubikasikan: 16-07- } \\
2021\end{array}$ & $\begin{array}{l}\text { Pelatihan pembuatan stik kangkung pada program pengabdian kepada } \\
\text { masyarakat yang dilaksanakan oleh Program Studi Biologi bertujuan untuk } \\
\text { memberikan pengetahuan dan keterampilan pada guru dan siswa SMA } \\
\text { Wijaya Putra Surabaya tentang aplikasi ilmu dan teknologi dalam } \\
\text { menghasilkan stik yang berasal dari kangkung. Peserta berasal dari guru } \\
\text { dan siswa SMA Wijaya Putra Surabaya. Metode pelaksanaan kegiatan ini } \\
\text { yaitu secara virtual dengan menggunakan platform virtual web } \\
\text { conferencing. Berdasarkan penyampaian tentang kandungan dan manfaat } \\
\text { kangkung, maka potensi kangkung dijadikan olahan stik sangat berguna } \\
\text { agar masyarakat yang tidak suka mengkonsumsi sayur secara langsung } \\
\text { dapat menjadikan stik kangkung sebagai alternatif. Selain itu, kejelasan } \\
\text { narasumber dalam memberikan informasi memiliki persentase sebesar } \\
\text { 81,3\%. Poin selanjutnya yaitu persentase kejelasan gambar yang diterima } \\
\text { mitra saat narasumber melakukan zoom cloud meeting sebesar } 78,3 \% \text { dan } \\
\text { sebesar } 31,7 \% \text { mitra yang menyatakan kejelasan gambar yang kurang } \\
\text { bagus. Hasil evaluasi setelah berlangsungnya kegiatan yaitu mitra akhirnya } \\
\text { mengetahui kandungan dan manfaat kangkung serta olahan kangkung yang } \\
\text { dapat menarik perhatian pembeli serta mengetahui tentang bagaimana } \\
\text { teknik pengemasan dan pemberian label yang baik. }\end{array}$ \\
\hline
\end{tabular}

\section{Abstract}

\section{Keyword:}

Kale, community service program, sticks
The training on making kale sticks in the community service program carried out by the Biology Study Program aims to provide knowledge and skills to teachers and students of SMA Wijaya Putra Surabaya about the application of science and technology in producing sticks from kale. Participants came from teachers and students of SMA Wijaya Putra Surabaya. The method of implementing this activity is virtual using a virtual web conferencing platform. Based on the delivery of the content and benefits of kale, the potential for kale to be processed into sticks is very useful so that people who do not like to consume vegetables directly can make kale sticks as an alternative. In addition, the clarity of sources in providing information has a percentage of $81.3 \%$. The next point is the percentage of image clarity that partners receive is $78.3 \%$ and $31.7 \%$ of partners who state that image clarity is not good. The results of the 
evaluation after the activity took place is the partners finally found out the content and benefits of kale and processed kale that can attract the attention of buyers and know about good packaging and labeling techniques.

\section{PENDAHULUAN}

Saat ini sebagian besar produk jajanan dipasaran terbuat dari $80 \%$ tepung terigu (Ladamay \& Yuwono, 2014). Untuk memperkaya nilai gizi produk dilakukan penambahan serat dan vitamin dengan memanfaatkan sayuran. Salah satu sayuran yang mudah didapat di pasar adalah kangkong. Kangkung merupakan sayuran yang sering dikonsumsi masyarakat. Komoditi ini tergolong sebagai sayuran sumber serat makanan yang tinggi. Kangkung sebagai komoditas sayuran memiliki prospek yang tinggi untuk peningkatan pendapatan masyarakat. Selain itu, kangkung memiliki kandungan gizi yang cukup tinggi terutama vitamin A, vitamin $\mathrm{C}$, zat besi, kalsium, protein, fosfor, karoten dan sitosterol ((Sofiari, 2016); (Kurniasih \& Ayu Dewi, 2019); (Hidayati et al., 2017)).

Kangkung selama ini oleh masyarakat diolah menjadi sayuran yang banyak anak-anak kecil maupun remaja tidak suka mengkonsumsi sayuran. Permasalahan tersebut dapat diminimalisasi dengan pengolahan kangkung menjadi produk yang umumnya digemari oleh masyarakat. Salah satu produk olahan tersebut adalah stik.

Stik adalah salah satu makanan ringan atau salah satu jenis kue kering berbahan dasar tepung terigu, tepung tapioka atau tepung sagu, mentega, telur, dan air, yang berbentuk pipih panjang dan cara memasaknya digoreng (Pratiwi, 2013). Inovasi dalam mengembangkan produk stik telah dilakukan oleh produsen stick, diantaranya inovasi pada bahan baku pembuatan stik dengan penambahan sayuran maupun hasil perikanan (Sutanti \& Mutiara, 2017).

Menurut SNI 01-2973-1992 stik memiliki kandungan air, protein, asam lemak dan abu. Protein yang ada pada stik dengan kadar yang rendah memiliki peranan dalam pertumbuhan tubuh manusia, yaitu sebagai alat pembangun menggantikan jaringan yang rusak dan mengatur metabolisme tubuh (Poedjiadi, 2005). Kandungan protein yang ada pada kangkung dapat dimanfaatkan sebagai bahan menambah kandungan gizi pada stik.

Pelatihan pembuatan stik kangkung pada program pengabdian kepada masyarakat yang dilaksanakan oleh Program Studi Biologi bertujuan untuk memberikan pengetahuan dan keterampilan pada guru dan siswa SMA Wijaya Putra Surabaya tentang pengaplikasian ilmu dan teknologi dalam menghasilkan stik yang berasal dari kangkung. Dengan adanya kegiatan ini dapat menumbuhkan minat dan kreativitas guru dan siswa SMA Wijaya Putra pada bidang teknologi pengolahan hasil pertanian dan pengaplikasian dalam kehidupan sehari-hari.

\section{METODE}

Peserta program pengabdian kepada masyarakat Prodi Biologi FST UNIPA berasal dari guru dan siswa SMA Wijaya Putra Surabaya. Metode dan tahap pelaksanaan kegiatan ini meliputi: 
a. Metode pelaksanaan secara virtual

Semakin pesatnya perkembangan ilmu pengetahuan berdampak positif terhadap perkembangan teknologi virtual digital pada dunia pendidikan, ekonomi, kesehatan dan lainnya (Putra, 2018). Pada program pengabdian berlangsung pada saat Pandemi Covid-19 maka penerapan social distancing dilakukan dengan cara berkomunikasi dengan peserta pengabdian menggunakan media zoom cloud meeting. Aplikasi tersebut merupakan salah satu jenis metode virtual simulasi degan menggunakan platform virtual web conferencing (Verkuyl et al., 2018), sehingga pelaksanaan kegiatan pengabdian ini lebih efektif, efisien dan aman dalam masa pandemi.

b. Tahap Pelaksanaan Kegiatan:

1. Survey dan pengurusan surat ijin

Tujuan pada kegiatan ini adalah untuk mencari informasi dan pengurusan perijinan pelaksanaan.

2. Sosialisasi

Sosialisasi kegiatan yang akan dilakukan kepada Kepala Sekolah SMA Wijaya Putra yaitu menjelaskan bagaimana kegiatan akan dilakukan melalui aplikasi zoom cloud meeting.

3. Pelaksanaan kegiatan

a. Mempersiapkan tempat dan sarana yang akan digunakan pada waktu kegiatan

b. Mempersiapakan jadwal kegiatan dan materi yang akan disampaikan

c. Mempersiapkan video praktek pembuatan stik kangkung

d. Persiapan peserta dengan mengingatkan untuk bergabung dalan aplikasi zoom.

e. Penyampaian materi.

c. Evaluasi

Bentuk evaluasi dari kegiatan pengabdian ini adalah dengan pengisian beberapa pertanyaan yang disediakan pada google formulir.

\section{HASIL DAN PEMBAHASAN}

Penyampaian materi tentang keutamaan tanaman kangkung meliputi taksonomi, kandungan dan manfaat, cara memilih kangkung yang baik dan pembuatan stik kangkung pada mitra dengan metode virtual berdasarkan hasil pretest dan post test didapatkan persentase pemahaman yaitu sebesar $80,5 \%$. Mitra mengetahui bagaimana karakteristik kangkung yang segar dan kandungan kangkung yang sangat baik untuk dikonsumsi.

Menurut (Hidayati et al., 2017), setiap 100 gram kangkung mengandung energi sebesar 29 kkal, protein 3 gram, lemak 0,3 gram, karbohidrat 5,4 gram, serat 1,0 gram, kalsium $73 \mathrm{mg}$, fosfor $50 \mathrm{mg}$, zat besi 2,5 mg, Vitamin A 6300 SI, Vitamin B 0,07 mg, Vitamin C $32 \mathrm{mg}$, klorofil $25 \mathrm{mg} / \mathrm{L}$, dan air 
89,7 g. Berdasarkan kandungan tersebut kangkung dapat memcegah beberapa penyakit seperti anemia, diabetes, menyehatkan mata, menjaga kesehatan jantung dan lain-lain.

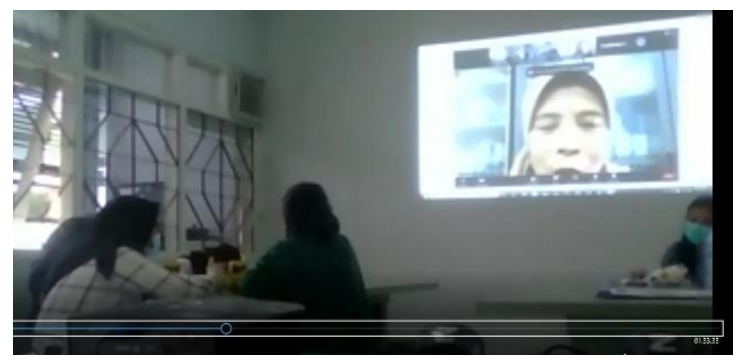

Gambar 1. Penyampaian Materi

Berdasarkan penyampaian tentang kandungan dan manfaat kangkung, maka potensi kangkung dijadikan olahan stik sangat berguna agar masyarakat yang tidak suka mengkonsumsi sayur secara langsung dapat menjadikan stik kangkung sebagai alternatif. Selain itu, kejelasan narasumber dalam memberikan informasi memiliki persentase sebesar $81,3 \%$. Mitra memberikan pernyataan bahwa materi yang disampaikan oleh narasumber dan bahasa yang digunakan saat penyampaian materi dapat diterima. Poin selanjutnya yaitu persentase kejelasan gambar yang diterima mitra saat narasumber melakukan zoom cloud meeting sebesar 78,3\% dan sebesar $31,7 \%$ mitra yang menyatakan kejelasan gambar yang kurang bagus. Hal ini disebabkan adanya kendala jaringan internet yang kurang baik ketika pelaksanaan.

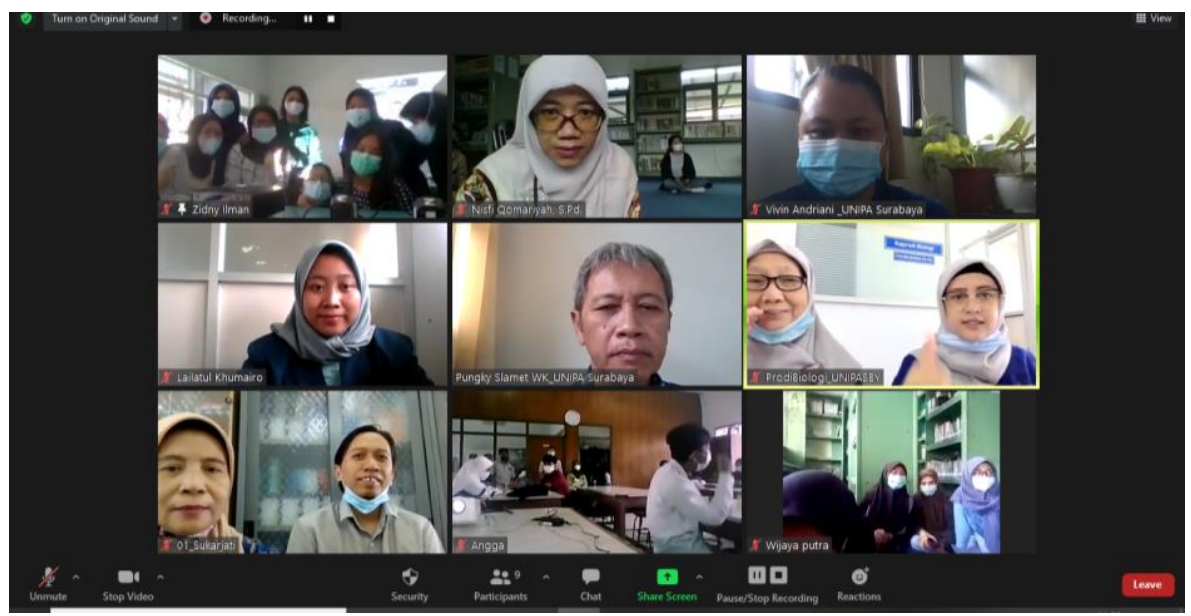

Gambar 2. Ruang zoom cloud meeting

Hasil evaluasi setelah berlangsungnya kegiatan dianalisis dari hasil pretest yang mana ternyata kurang dari 50\% mitra belum mengetahui tentang kandungan, manfaat dan pengolahan kangkung, namun dari hasil post test pada akhir kegiatan, 92\% mitra akhirnya mengetahui kandungan dan manfaat kangkung serta olahan kangkung yang dapat menarik perhatian pembeli serta mengetahui tentang bagaimana teknik pengemasan dan pemberian label yang baik. 


\section{KESIMPULAN}

Kegiatan pengabdian ini dilaksanakan secara daring dengan menggunakan aplikasi zoom cloud meeting. Kegiatan pengabdian ini dapat menambah pengetahuan guru dan siswa SMA Wijaya Putra Surabaya mengenai kandungan, manfaat, pengolahan kangkung menjadi stik, dan pengemasan serta pelabelan produk sebesar 92\%. Pada kegiatan pengabdian masyarakat yang akan datang tim akan meningkatkan kualitas gambar dengan cara perperkuat jaringan internet yang digunakan.

\section{UCAPAN TERIMA KASIH}

Penulis mengucapkan terima kasih kepada Universitas PGRI Adi Buana Surabaya yang telah memberi dukungan dana terhadap kegiatan pengabdian kepada masyarakat ini.

\section{DAFTAR PUSTAKA}

Dewi, C. A., \& Kurniasih, Y. (2018). Pemberdayaan Petani Jagung Melalui Pengembangan Usaha Diversifikasi Produk Olahan Jagung di Labuapi Kabupaten Lombok Barat. Lumbung Inovasi: Jurnal Pengabdian kepada Masyarakat, 2(1), 1-6. https://doi.org/10.36312/linov.v2i1.408

Hidayati, N., Rosawanti, P, Yusuf, F., Hanafi, N. (2017). Kajian Penggunaan Nutrisi Anorganik Terhadap Pertumbuhan Kangkung (Ipomoea reptans Poir) Hidroponik Sistem Wick. Jurnal Daun, 4(2), 75-81.

Kusumawardhani, Rahardian; Tyas, Titis A. (2015). Pemanfaatan Jerami Padi Menjadi Pupuk Organik Dan Wahana Budidaya Belut Oleh Masyarakat Desa Wonorejo. Seminar Nasional Universitas PGRI Yogyakarta. ISBN 978-602- 73690-3-0

Ladamay dan S.S. Yowono. (2014). Permanfaatan bahan local dalam pembuatan makanan. Jurnal Pangan dan Agroindustri. 2(1): 67-68. https://jpa.ub.ac.id/index.php/jpa/article/view/23

Poedjiadi Anna. (2005). Dasar-dasar Biokimia. Jakarta: UI Press

Pratiwi, F. (2013). Pemanfaatan Tepung Daging Ikan Layang Untuk Pembuatan Stik Ikan. Skripsi. Fakultas Teknik. UNNES.

Putra, R. A. (2018). Peran Teknologi Digital Dalam Perkembangan Dunia Perancangan Arsitektur R. Elkawnie: Journal of Islamic Science and Technology, 4(1), 67-78. www.jurnal.arraniry.com/index.php/elkawnie

Sofiari, E. (2016). Karakterisasi Kangkung (Ipomoea reptans) Varietas Sutera Berdasarkan Panduan Pengujian Individual. Buletin Plasma 49. https://doi.org/10.21082/blpn.v15n2.2009.p49-53

Sutanti, S., \& Mutiara, E. (2017). Industri Rumah Tangga Stik Wortel di Deli Serdang. Jurnal Pengabdian Kepada Masyarakat, 23(2)

Verkuyl, M., Atack, L., McCulloch, T., Liu, L., Betts, L., Lapum, J. L., Hughes, M., Mastrilli, P., \& Romaniuk, D. (2018). Comparison of Debriefing Methods after a Virtual Simulation: An Experiment. Clinical Simulation in Nursing, 19, 1-7. https://doi.org/10.1016/j.ecns.2018.03.02 